\title{
MAJAPAHIT AND THE CONTEMPORARY KINGDOMS: INTERACTIONS AND VIEWS
}

\section{MAJAPAHIT DAN NEGERI-NEGERI SEZAMAN: INTERAKSI DAN PANDANGAN}

\author{
Agus Aris Munandar \\ Departemen Arkeologi, Fakultas Ilmu Pengetahuan Budaya, Universitas Indonesia \\ agus.aris@ui.ac.id
}

\begin{abstract}
This study discusses the interactions between Majapahit and other kingdoms from a contemporary time in Nusantara, Southeast Asia, India, and China and vice versa. The aim is to formulate the interaction between Majapahit and contemporary kingdoms and vice versa based on existing data. This is an ancient historical study that was conducted in three stages, namely: collecting data contained in written sources such as inscriptions, literary works, and Chinese chronicles, and archaeological data. The second stage was a data analysis by linking data from written sources with other data, to look for elements that support each other, and always refer to the phenomenon of the study framework. The third stage included an interpretation to gain conclusions. According to the data analysis by examining Majapahit's contemporary regions and kingdoms, it turned out that the kingdom applied the basic concept of Tri Angga which refers to the macrocosm concept of Tri Loka. Majapahit's relationship with India is not as dynamic as that of China, instead, there is a view that India is religiously no longer a reference to Hinduism and Buddhism.
\end{abstract}

Keywords: Nagarakrtagama; Nusantara; views; inscription; Chinese Chronicle; India

\begin{abstract}
ABSTRAK
Kajian ini dilakukan berkenaan interaksi antara Majapahit dengan negeri-negeri lain pada masa yang sama di kepulauan Nusantara, Asia Tenggara, India, dan Cina dan sebaliknya. Pemahaman yang hendak diperoleh adalah merumuskan perihal interaksi antara Majapahit dengan negeri-negeri sezaman dan sebaliknya. Telaah yang dilakukan berada dalam ranah sejarah kuno dengan tiga tahap kajian, yaitu mengumpulkan data sumber tertulis seperti prasasti, karya sastra dan Berita Cina, dan data arkeologis. Tahap kedua melakukan analisis dengan mengaitkan data sumber tertulis dengan data yang lain, untuk mencari elemen yang saling mendukung dan mengacu kepada fenomena kerangka kajian ini. Tahap ketiga adalah penarikan interpretasi untuk mengarah kepada kesimpulan. Berdasarkan kajian ini, diketahui bahwa dalam memandang daerah dan kerajaan yang berkembang sezaman, ternyata Majapahit menerapkan konsep dasar Tri Angga yang mengacu kepada konsep makrokosmos Tri Loka. Hubungan Majapahit dengan India tidak sedinamis dengan Cina, malahan terdapat pandangan bahwa secara religius India bukan lagi menjadi acuan keagamaan Hindu dan Buddha.
\end{abstract}

Kata Kunci: Nagarakrtagama; Nusantara; pandangan; Berita Cina; India

Article Submitted : : 29-01-2020

Article Accepted : : :04-04-2020 


\section{INTRODUCTION}

There have been many discussions of the Majapahit Kingdom in its various aspects, for example of religious life, government system, archaeological heritage, public order, etc. Even this study discusses Majapahit, but only one aspect, i.e. regarding the relationship between Majapahit and the regions in Nusantara, Southeast Asia, India, and China. It is well known that in the description of Mpu Prapanca's Kakawin Nägarakŗtägama, which was completed in 1365, there is mention of areas outside Java which recognize the glory of Majapahit. The recognition of this glory was a form of respect for Majapahit who was at the peak of its splendor, but could not be interpreted that the other areas were controlled by Majapahit. Regarding other regions outside Java (Nusantara), Mpu Prapanca describes in two pupuh (a form of Javanese and Sundanese traditional poem), namely pupuh 13 and pupuh 14. Some areas are in Sumatra, Malay Peninsula, and also Kalimantan (Borneo), Sulawesi (Celebes), Maluku (Moluccas), Nusa Tenggara, as well as the coast of West Papua. Line 1 pupuh 15 of Kakawin Nägarakrtāgama mentions the existence of Majapahit's friendly kingdoms (Mitra Satata) as follows: Syangka (Siam), Ayodhyapura (Ayuthia, inland of Thailand), Darmanagari (Dharmarajanagara/Ligor), Marutma (Martaban, Martaban, on the east coast of Myanmar, Rajapura (Rajjpuri, southern Thailand), Singhanagari (an area in Menam Riverside), Campa, Cambodia, and Yawana (Annam, Vietnam).

The big kingdoms in Asia which are certainly well-known by Majapahit people are China and India. The interesting thing is that China as one of the biggest kingdoms in Asia at that time and was not mentioned by Mpu Prapanca as one of the Majapahit's Mitra Satata (friendly kingdoms). However, it is undeniable that several remains show the influence of Chinese culture found at a site of Trowulan (the former city of Majapahit located in Mojokerto Regency now). Regarding India, Mpu Prapanca mentions some areas in the region. It can be interpreted that merchants are coming from these areas, so it is known by people of Majapahit and recorded by Prapanca. In pupuh 83: 4 and 93: 1, Nāgarakṛtāgama mentions several kingdoms where merchants and educated people (scholars) came from, namely priests and monks. These kingdoms are (1) Jambhudwipa which is none other than the common name for India, (2) China, (3) Karnataka, regions in southern India, (4) Goda, areas in eastern India, and (5) Kancipuri or now called Conjeveram in India. Nägarakrtāgama does not mention these kingdoms as Mitra Satata, but as kingdoms whose merchants visited Majapahit area in the eastern part of Java (Pigeaud, 1962, pp. 35-36).

Regarding the study of Majapahit's views on other kingdoms in Southeast Asia and vice versa, it has never been conducted. The study that has been conducted only discusses the position of each kingdom in general, for example, conducted by D. G. E. Hall in his book History of Southeast Asia (1988), only mentions the development and collapse of contemporary kingdoms in Southeast Asia. Likewise, the work of Renee Hagesteijn Circles of Kings: Political dynamics in early continental Southeast Asia (1989) describes the growth and replacement of kings in mainland Southeast Asia, without discussing the influence of other kingdoms in Southeast Asian islands. Paul Michel Munoz, in his book titled Kerajaan-Kerajaan Awal Kepulauan Nusantara dan Semenanjung Malaysia: Perkembangan Sejarah dan Budaya Asia Tenggara (Jaman Prasejarah-Abad XVI)-- 
(Early Kingdoms of the Indonesian archipelago and the Malay Peninsula: Development History and Culture of Southeast Asia (Prehistoric Ages - XVI Century) (2009) describes the formation of earliest kingdoms in Southeast Asia until the 16th century comprehensively, but did not include the views of inter-kingdoms towards the others. Thus, there is an opportunity to discuss proposed issues in this brief study about interaction and view of kingdoms in Southeast Asia, India, and China, especially Majapahit's views of other kingdoms in the same regions. Therefore, this study aims to fulfill knowledge of Majapahit Kingdom, thus not only discusses the implementation of government in his kingdom but also seeks to explain the mutual relationship between Majapahit with other kingdoms approximately in the same periods.

\section{METHODS}

The study is included in the field of the ancient history of Indonesia. Therefore, to complete the study, it is used the description of written sources in the form of inscription, literary works, and foreign news, particularly the records of China, in this case, the archaeological data only as supporting of stated statements. The importance of written sources for historical studies according to S. O. Robson is because literary works, inscriptions, and written sources are the nature of people's minds and lives that have become data. Present researchers can communicate with the public and their views by studying the written source (Robson, 1994, p. 8). In brief, the methods used in this study to examine the written source are as follows:

1. Collecting data was the first step in the study. The data is in the form of written sources, manuscript descriptions, Chinese news, and narratives of several inscriptions. Data must be following the problem to be answered or explained. The selected data is a description of written sources originating from several contemporary or younger literary works that are still relevant to the problem. In the text, it is usually reflected in the mind, views, ideals, religious teachings, politics, etc. (Pudjiastuti, 2016, p. 251). Relevant narrative later can be used as the data to answer research problems. Likewise, only relevant narratives from foreign sources (India and China) can be used to help answer the problem.

2. The second step was conducting a review and integration of data following efforts to answer research problems. The analysis is done by linking data with other data and always refers to the phenomenon of the study framework that has been determined. The analysis is in the form of activities of linking and integrating data within the same study framework, namely the Majapahit period regarding the interaction of the kingdom with other contemporary kingdoms.

3. The third step was in the form of data synthesis of analysis results, observed, and answered several propositions regarding the problem. Process analysis and synthesis from the data source is a written interpretation of the past achievement of the society, which is partly recorded in the manuscript (Ikram, 2019, pp. 2-3). Certainly, the text referred to in the broadest sense, namely written sources, means that 
interpretation is done to explain and answer the problem. The interpretation must be expressed in the narrative in the form of writing scientific papers. This step formulated the view of Majapahit towards foreign kingdoms and vice versa, maybe foreign kingdoms also have certain views of Majapahit.

\section{RESEARCH RESULTS}

As a kingdom that has the biggest and the last Hindu-Buddhist culture that developed in Nusantara, Majapahit has many historical sources that remember the greatness. Some of these sources describe straightforwardly about Majapahit, but there are also some which describe it in the form of metaphors. In the case, other kingdoms have their views on Majapahit, certainly, in the form of admiration, regard as equals, and some despise it. The following discusses the various sources regarding these views.

\section{Majapahit and The Regions in Nusantara}

Regarding the relation between Majapahit and other regions in Nusantara, which means that on other islands outside of Majapahit, mentioned in the book of Nägarakŗtāgama in pupuh 13-14 (Pigeaud, 1960, pp. 11-12 and pp. 16-17) some regions often send messengers to Majapahit. Some areas on Sumatra Island mentioned by Mpu Prapanca include Malayu, Jambi, Palembang, Karitang, Teba (Muaro Teba), Dharmmasraya, Minangkabwa, Siyak, Parlak, Pane, Mandahiling, Tamihang, Barus, and Lampung. In Kalimantan island, the areas mentioned are Tanjung-Nagara, Kapuhas, Katingan, Sampit, Kuta-Lingga, Kuta-Waringin, Sambas, Lawai (Muara Labai), Kadangdangan, Landa, Samedang, Sedu, Buruneng, Saludung, Pasir, Baritu (Barito), Tunjung-Kute, and Tanjung-Puri.

In Malay Peninsula, several regions are mentioned, namely Pahang, Hujung Medini (Johor), Langkasuka (Lengkawi), Kalanten, Tringgano, Pakamuwar (Muwar), Keda, Jere (Bukit Jerai), and Tumasik. Areas in eastern Java, mentioned in Nägarakŗtāgama, include Bali, Badahulu, Lwa Gajah, Gurun (Nusa Penida), Taliwang, Dompo, Sanghyang Api (Volcano, or Sangeang Island), Bhima, Sheran (Seram), Lombok -Mirah, Saksak, Luwuk, Makasar, Butun (Buton), Salaya, Sumba, Wandan, Ambwan, Wwanin (Onin), Seran, and Timor (Pigeaud, 1962, pp. 30-34). The regions seemed to be recognized by Majapahit people, thus Mpu Prapanca included the names of these regions in Nägarakrtägama.

In the book of Malay History, it is reported that there is a connection between Majapahit, Tanjungpura, Malacca, and Bukit Siguntang where the Malay tribes originate. One time the king of Majapahit died, did not have a crown prince, then Gajah Mada made king's daughter named Galoh (Galuh) Wi Kusuma being a queen. This princess married to the prince of Tanjungpura king piut Sang Maniaka from Bukit Siguntang. Then the marriage of Wi Kusuma and Ki Mas Jiwa (prince of Tanjungpura), gave birth to a daughter named Galuh Candrakirana. King of Tanjungpura was very happy to hear that his son could become king in Majapahit, he also sent an envoy to Java, and then it became well-known that king of Majapahit was the son of King Tanjungpura. Later, Galuh Candrakirana married 
to Sultan Mansur Syah from Malacca, then there was a family relationship between Majapahit and Malacca. Malay history also reports that the king of Majapahit was married to the daughter of the king of Bukit Siguntang, having two sons. The eldest son succeeded his father as king in Majapahit. He attacked Singapore which is not submissive to Majapahit, but Singapore can still survive and Majapahit soldiers returned (Sutrisno, 1985, pp. 356 - 357). The description of the Malay History is certainly different or contradictory with authentic sources about the Majapahit Kingdom. However, the text already has its view of Majapahit, in that view, the position of Majapahit remains important, but has a close relationship with Malay kingdoms and the position of Majapahit with these kingdoms in the description of Malay History is equal.

Hikayat Banjar mentions that after Negara-Dipa existed, developed, and became prosperous, many merchants from various regions came to trade in the city. On one occasion, King of Negara-Dipa said:

"We have done nagri sandiri (own kingdom), according to tradition way of Majapahit Kingdom. So, our clothes are similar to Javanese clothing. Then chabar tjarita (story) of the old men, long ago: when the people of nagri obeyed the clothes of other nagri, it is the arrival of sangsara (misery)" (Ras, 1968, p. 264).

With a clear description of Hikayat Banjar asking all the people of the NegaraDipa kingdom to follow the procedures of Majapahit civilization, it was even seen that the procedures of the Majapahit civilization were the best. The procedures of other kingdoms are considered bad and will bring misery. The description shows that civilization in Majapahit has become a reference for the development of new Nusantara kingdoms, including Negara-Dipa in southern Kalimantan.

In the Silsilah Kutai manuscript, it is stated that the king of Kutai Batara Agung Dewa Sakti once plunged his rooster to Majapahit. Returning from Majapahit he drowned himself with his boat (maybe because the rooster was defeated by Majapahit's rooster). His position was replaced by his son named Paduka Nira, the king was later replaced by his son also named Sultan Maharaja. The new king and his brother went to Majapahit to learn the customs and governance of Majapahit state, they learned from all the ministers in the palace. Upon returning to Kutai, he built a palace in the style of a Javanese palace, equipped with a gate that was brought from Majapahit (Sutrisno, 1985, pp. 360). The description again shows that the Majapahit civilization is indeed worthy of being used as a reference for other regions in Nusantara.

An example is that the achievement of the Majapahit civilization which was appreciated by other regions in Nusantara and Southeast Asia was the spread of the Panji stories that came from the late Majapahit era. The acceptance of the Panji Stories by the people in Southeast Asian kingdoms is a form of recognition of the glory of Majapahit itself. Panji stories have several features in the description of her, among others: (1) Panji stories may be a reference value of heroism, appreciation to humanity, ethics of polite and equal association, and diplomacy. Therefore, Panji Stories deemed to have universal value outstanding, (2) narrative Panji Stories is one proof of the work that is a masterpiece. The story was composed by ancient Javanese poets, not stories from India, showing the creativity of local writers. Panji stories described the setting of the story takes place in Java with the 
theme of romantic and heroic of prince and princess of ancient Javanese kings, but the story can be accepted by the society and culture in Southeast Asia regions, (3) In his description, Panji stories reveal the stages in the life history of humanity. The story produced a form of cultural history documentation in Java between the 14 th and $15^{\text {th }}$ century which was widely accepted by contemporary Southeast Asian peoples. (4) The Panji stories were authentically composed. There were no previous works with the same theme, the story did not imitate or copy other works. The theme of romance is indeed universal, but in Panji stories, the theme is reprocessed with the spices of ancient Javanese culture, so it is a typical Javanese story and does not refer to stories from any region that have been known beforehand, (5) in the same period also produced other stories, like the story of Dewi Sri Tanjung, Sudhamala, and Calon Arang, but Panji Stories is a genre specifically for narrative romance (Munandar, 2014, pp. 16-17). Considering that the stories spread far beyond his native land in East Java of the Majapahit era, it can be stated that the Panji Stories is a very successful form of cultural diplomacy media from Majapahit.

The greatness of Majapahit was evidenced by the relics of artifacts and religious monuments in the East Java region and also the records of migrants from China. Majapahit deserves to be a kingdom of reference in Nusantara during the 14th-15th century, especially throughout the 14th century when Hayam Wuruk was at the peak of his greatness. According to several written sources in the 14th century, Majapahit's fleet made direct visits to several regions of Nusantara. Majapahit armies attacked areas needing to be subdued. In the Chinese records, in the eastern coastal region of northern Sumatra, near Deli there is now a kingdom called Aru, this kingdom was once controlled by troops from Majapahit in 1350 until throughout the 14th century. In 1460, Aru was free from Majapahit but later was controlled by Aceh (Cribb \& Audrey Kahin, 2012, pp. 37). In the second half of the 14th century, there was an invasion of armies from Java to Suvarnabhumi, Chinese news of Ming Dynasty noted that the attack took place in 1377. The Javanese referred to around these years must have been Majapahit, the reason for the Majapahit attack was stated in Chinese news that in 1373 King Suwarnabhumi sends an envoy to China, without the knowledge of King Majapahit. Of course, King Suwarnabhumi's behavior was considered as impudence and fault of Suvarnabhumi who at that time was under the influence of Majapahit. After the attack, the crown prince of Suvarnabhumi did not dare to announce himself as the new king of Suvarnabhumi, he was afraid of the power of Java, so the crown prince sent an envoy to ask for help and approval from the Chinese emperor. The Chinese authorities then sent a letter of approval and appointment of the crown prince Suvarnabhumi as the new king, but unfortunate envoys from the Chinese Emperor were intercepted and killed by the Javanese army on their voyage to Suvarnabhumi. The interesting thing is that after the Chinese Emperor heard the envoy killed, he did not retaliate from Java. According to Chinese news, acts against Java is useless, because the location of Java was difficult to reach directly by the power of China (Groeneveldt, 1960, p. 69; Muljana, 1979, p. 142).

Thus, the regions under the influence of Majapahit each year sent envoys to the Majapahit palace, as a sign of appreciation and admiration for the greatness of Majapahit. There is no evidence that the Majapahit forces directly controlled these 
areas, moreover sending their troops to conquer areas in Sumatra, Malay Peninsula, Kalimantan, Sulawesi, and other areas of eastern Java. One thing that can be ascertained is that the greatness of Majapahit was heard throughout Nusantara, of course, the news brought and spread it. Regarding who heralds concerning the greatness of Majapahit to Nusantara and Southeast Asia region, hypothetically there are two groups, namely:

1. Merchants from Java (Majapahit) who sailed to areas of Nusantara and Southeast Asia.

2. Merchants from outside Java (Nusantara), Southeast Asia, China, and Jambhudwipa who brought news of greatness of the time back to his native land.

With this kind of preaching, news gradually came out of the prosperous Majapahit, big population, a large city and the number of foreign merchants stopped at its ports to overseas regions to the mainland of Southeast Asia.

\section{Majapahit and The Kingdoms outside Nusantara}

Majapahit also interacted with other kingdoms outside Nusantara, especially with kingdoms in Southeast Asia. In the book Nāgarakrtāgama stated as follows:

$$
\text { “... }
$$

tuhun/tạ syańkāyodyapura kimutay darmmānāgarî, marutma mway riy rajapura nguniweh sińhanaragari,

ri campa kambojanyat i yawana mitreka satatā (Nag. pupuh 15:1, Pigeaud., 1960, p. 12)

Translation:

(... as for Syangka, Ayodhyapura, not forgotten Darmmanagari, Marutma, and Rajapura, including Singhanagari, Campa, Cambodia, Yawana, they were equal friend ")

Mpu Prapanca mentions that some kingdoms in Southeast Asia as Mitra Satata or friendly kingdoms which were equal to Majapahit. Perhaps the relationship between Majapahit and the kingdoms is like the current state-to-state relations scheme, they respect each other, no intervene, and also help each other when needed. The kingdoms mentioned in the Nägarakrtägama have survived until now, and many have merged with the modern state system today.

According to the study of Th. G. Th. Pigeaud (1962), Syangka is also called by the old name Siam for Muang Thai or Thailand. Ayodhyapura is one of the kingdoms in the region of Thailand also now called Ayuthia or Ayutthaya. Dharmanagari is also called Dharmmarajanagara which is located in southern Thailand, in the Ligor region. Marutma is the old name of Martaban or also called Mergui, an area on the coast in eastern Myanmar, while Rajapura or also called Rajpuri/Ratburi, the kingdom located on the coast of Siam bay. The Singhanagari or Singhapuri is located in the Menam River branch, in one of the inscriptions from Campa also called Singhapura. The Campa region is none other than the Kingdom of Campa which was once in the southern part of Vietnam, Cambodia is the Khmer today and is still known as a unitary state. Yawana is an area in Vietnam that may 
have a lot of people who embrace Islam. Many Indian sources refer to Yawana as an area inhabited by Muslims, perhaps such an area that once developed in Vietnam (Pigeaud, 1962, p. 35).

There are no reports or ancient Javanese sources that describe the condition of the kingdoms mentioned in the Nägarakrtägama as Mitra Satata to Majapahit. The condition of some of these areas can be known from reports of Chinese sources, including records carried out by Ma-huan and Fei Xin, two educated Chinese who participated in the sailing with the Admiral Cheng-ho. But the Chinese records of a particular kingdom or region is not the same thing that was reported. What they find interesting in certain kingdoms or regions, that's what was recorded. Thus, there is no similar data in their report, even systematic data as expected by researchers in the future. Thus, the kingdoms of Mitra Satata known the condition due to note of Ma-Huan and Fei Xin who participated in the course of Cheng-Ho, as follows:

\section{Campa}

In the city of Campapura, there is a royal palace, its walls neatly arranged from bricks. The palace is quite spacious with a long-tiled roof, surrounded by a fortress with walls made of four-door stone, with carved doors, its gate is heavily guarded. The king was a Buddhist, wearing a golden crown and a long cloth, his waist was wrapped with a colorful silk cloth, and the king was not wearing footwear. If he travels was on an elephant or using cikar (two-wheeled bullock cart) which is pulled by two cows. The village head (leader/regional official) wears a cap with a little gold jewelry. The roof of residential housing is made of grass with a low roof, so someone who enters the door must bow his head. The Campa people have blackish skin, wear cloth up to knee, waist wrapped around silk fabric, they also don't wear footwear. In trading, Campa people using gold and silver coins whose authenticity is 70\%, they like goods from China including beads, the items are exchanged for gold coins. Envoys of Campa, when visiting the imperial palace of China, they will bring rhino horns, ivories, and perfumes (Yuanzhi, 2011, pp. 162-167).

\section{Cambodia}

The Book of Nägarakrtāgama refers to the kingdom in mainland Southeast Asia like Cambodia, also known as the Khmer. According to Fei-Xin's record following Admiral Cheng-Ho's sea voyage, the condition of Cambodia was briefly explained as follows:

This kingdom's old name is called Chen-la (Zhen-la), the capital city is surrounded by walls, each side is about $35 \mathrm{~km}$, on the edge of the river which is about $200 \mathrm{~m}$ wide. Around the city, there are about 30 sacred buildings (temples), and every year a religious celebration ceremony is held at the temples, at that time peacocks, white elephants, rhinos, and other animals are shown. It was during this celebration that locals ate using gold bowls and plates, so Cambodia is famous for its wealth.

The climate in Cambodia is hot all year long, many diverse plants, residents make salt from seawater, they wear short-sleeved clothes, the lower part of the body is 
covered with a sarong, both men and women in a bun, because of long hair. The law is very hard to run, if someone violates the law, his face will be injured, as a marker of guilt. The robber chopped off his hand. Murderers can be killed again or fined with gold or made slaves by the king. The goods traded are peacock feathers, yellow candles, fragrant wood, and other fragrances. Cambodia also produced gold, silver, gem, and silk cloth (Yuanzhi, 2011, p. 168).

\section{Siam (Ancient Thailand)}

In Siam, according to Nāgarakrstāgama, several kingdoms were in the same period with Majapahit, namely Syangka, Ayodhyapura, and Darmmanagari. Mahuan and Fei Xin reported the condition of Siamese people that they visited in the 15th century, but the territory of the kingdom was not mentioned. It seems that people of the kingdoms in Siam have the same traditions and customs, even though they live in different cities. Briefly, the report of Ma-huan and Fei Xin is described as follows:

The royal palace is luxurious and clean, the king uses a white cloth headband, shirtless, and wears silk cloth. When traveling, the king rides on an elephant or a stretcher, one of his companions carries a royal umbrella made from cloth with a long golden handle. Buddhism developed in Siam, many monks, and nuns, living and praying in Buddhist temples.

Natural resources of Siam include good sepang (tree the wood of which produces a red dye), yellow candles, cardamom, incense, gold, silver, bronze, iron, mercury, bird feathers, horns, ivory, glassware, cotton cloth, suteram umbrella, etc. Chinese coin does not apply in Siam, the currency they use is made of gold, silver, and bronze, a kind of fine shell--valued and used as a currency.

West of Ayuthia (the capital of Siam) lies the city called Shangshui, approximately $200 \mathrm{li}(100 \mathrm{~km})$ from Ayuthia. From Shangshui to the south of Yunnan Province (Southwestern China), there is a busy connecting road for traders/merchants. Therefore, Shangshui developed as a trading city and was inhabited by $500-600$ families. The inhabitants of the city life from commerce with the inland areas of China, there is a valuable commodity, namely Yaqut stone, a pomegranate red gem. Kingdoms of Siam developed in commerce because it was done by sea because many Chinese merchants who stopped at his ports and overland through Shangshui (Yuanzhi, 2011, pp. 159-161).

This is the description of several kingdoms referred to as Mitra Satata for Majapahit according to Chinese reports. Why is it called "satata" by Mpu Prapanca, may because the conditions and people of these kingdoms are around the same in some cases with Majapahit which developed in the same period and also have the same geographical conditions. Based on the same conditions then Prapanca deserves to call it friendly kingdoms which are all located in the mainland Southeast Asia region.

Chinese reports also elaborate on a little condition of some areas in the Malay Peninsula stated by Nāgarakrtāgama, namely Pahang, Kelantan, and Johor. Together with other Nusantara regions, the three regions in the Malay Peninsula were also very likely to send envoys to Majapahit palace as a form of their appreciation to the greatness of Majapahit. 
Related to Pahang, Chinese records state that:

The kingdom is located on the west side of Siam, surrounded by Rocky Mountains, flat land, producing a lot of rice, the weather is warm. Their habits cannot be praised, they make human statues of fragrant wood so that their prayers can be recited. Often, they sacrifice human blood to hold ceremonial offerings to the statue. Men and women bun their hair and cover themselves with a cloth. They make salt by boiling seawater and make wine with sticky rice. Natural resources of this kingdom are gaharu (eaglewood), camphor, tin, and a kind of coloring wood. The imported goods are gold, silver, colored silk, Javanese cloth (batik), copper, iron tools, Javanese gongs, boards, etc. (Groeneveldt, 2009, p. 193).

A record about Kelantan stated as follows:

In 1412, Cheng-ho received an order from the Chinese emperor to visit Kelantan, carrying an imperial letter containing praise for the deeds of Kelantan King who had sent tribute to China in 1411. Cheng-ho also brought various kinds of silks to the king (Groeneveldt, 2009, p. 196).

The Cheng-ho fleet in the early 15th century passed by and stopped on an island called Tong-si-tiok, probably the name is Chinese pronunciation for Tumasik, or now called Singapore. According to Chinese records, the island has hills in the middle which can be seen from all directions of the sea, the land is barren, unsuitable for farming. The people get rice from the coast of Sumatra, they make salt by boiling seawater and make wine from coconut. Men and women cut their hair short, and cover the body with a striped cloth.

Tumasik is very likely part of Johor, because Chinese records equate the description between them, and are stated that the location is close, only separated by a narrow strait. Johor produces areca nuts, cotton cloth, and mats from banana tree fibers. Salable goods for sale in Johor include tin, pepper, iron, rice, and other types of equipment. Chinese records add that between 1573 and 1619 the king of Johor was very fond of war with his neighbor kingdoms, Inderagiri and Pahang suffered enough from the war with Johor. Resident houses with thatched roofs, around the city of Johor are strengthened by strong wooden fortresses. When the kingdom is safe, all residents trade with other kingdoms, but if in a state of war, all residents are called to become soldiers, therefore the land of Johor is strong. The soil is not fertile, so they buy rice from other kingdoms, mainly from Sumatra (Groeneveldt, 2009, pp. 190-192).

\section{DISCUSSIONS}

\section{Views Towards Majapahit and Vice Versa}

Based on the study by reviewing several written sources that were in the same period with the development of Majapahit, it can be concluded that there were some views of the Majapahit population towards other regions or kingdoms. Those views are more of a presumption that seems to develop in the Majapahit community when discussing other kingdoms. 


\section{Majapahit's Views of Nusantara Regions and Vice Versa}

The views of Majapahit people towards other kingdoms or regions in Nusantara including in the Malay Peninsula are as follows:

1. The kingdoms are regions that recognize the authority of Majapahit (Nag. Pupuh 13-14, Pigeaud, 1960, pp. 11-12).

2. They sent messengers voluntarily to Majapahit palace as a sign of recognition of Majapahit's greatness. Foreign guests also come voluntarily from Jambhudwipa, Cambodia, China, Yawana, Campa, and Karnnathaka, also of Goda and Syangka (kingdoms of Siam) (Nag. pupuh 83: 4, Pigeaud, 1960, p. 64).

3. The people of Nusantara kingdoms are merchants who often come to Majapahit ports on the north coast of East Java, such as Lasem, Tuban, Gresik, and Surabaya.

On the other hand, the views of Nusantara people living in various kingdoms and kingdoms toward Majapahit as follows:

1. A great kingdom in Java that should be respected, in the book Babad Dalem (Bali) states that king of Majapahit represents the top greatness that should be deepest respected (Son, 1995, p. 23). Malay history stated that Majapahit was one of the biggest kingdoms, the others are Pasai and Malacca. It was also stated that Majapahit was famous in all kingdoms, the king of which was the son of king Tanjungpura (Situmorang et al., 1952, p. 105 and 126).

2. Majapahit already had traditions and high cultural achievement in Nusantara. For example, the book Babad Dalem describes the splendor of Majapahit palace, ordinances in the front hall (paseban) when facing Hayam Wuruk, types of food and entertainment were presented to adipata (leader of a smaller region under a kingdom) when facing (Son, 1995, pp. 25-28). Hikayat Banjar mentions that Nagara-Dipa Kingdom in Kalimantan made the Majapahit civilization as their reference, i.e in awarding titles, dressing, arranging palaces, etc. (Ras, 1968, pp. 263 - 264).

3. Many Majapahit residents were rich and love to trade goods that are not produced by themselves. Majapahit harbor cities, including Gresik (Xincun) was very rich, many foreign merchant ships were anchored at their port (Groeneveldt, 2009, p. 57). Hikayat Banjar also states that after the king of Majapahit had 6 children, the kingdom became greater, many kings who surrendered to Majapahit, many merchants came to Majapahit ports, i.e. from Jambi, Palembang, Mangkasar, Pahang, Patani, Bali, Pasai, and Campa who traded in Majapahit (Ras, 1968, p. 292).

4. Majapahit had sufficient military power to attack other regions in Nusantara. It is mentioned in Nāgarakrtāgama pupuh 49:4 that the Majapahit army conquered Bali (Pigeaud, 1960, p. 36). The book Pararaton says that in 1357 AD (1279 Saka), the Majapahit army attacked and conquered Dompo (Padompo) on Sumbawa Island (Hardjowardojo, 1965, p. 53). It is described in a chronicle of Arya Kutawaringin (Bali), a powerful Majapahit army under the leadership of Patih Gajah Mada attacked Bali to conquer Pasung Grigis. The attack was carried out through landings from the north, 
south, and east coasts (Putra, 1991, pp. 8-9). This shows the strength of Majapahit with his army in large numbers.

5. People of the kingdoms tried to follow the traditions and culture that developed in Majapahit, as mentioned in the text of Banjar Hikayat (Ras, 1968, p. 264). The text of Silsilah Kutai states that the new king went to Majapahit to learn the customs and governance of Majapahit state, they learned from all the ministers in Majapahit. Upon returning to Kutai, he built a palace in the style of a Javanese palace, equipped with a gate that was brought from Majapahit (Sutrisno, 1985, p. 360). In Sejarah Melayu, it is stated that Sultan Mansur Syah from Malacca accompanied by all the kings of Inderagiri, Palembang, Jambi, Lingga, and Tungkal went to face Betara Majapahit. In Majapahit, they learned many things including the type of gamelan and wearing a dagger behind the back. After returning from Majapahit, they received a prize from Betara Majapahit (Situmorang et al., 1952, pp. 128-135).

\section{Majapahit's Views of the Mainland Southeast Asian Kingdoms and Vice Versa}

Regarding Majapahit's views of kingdoms in Southeast Asia and vice versa, the available data is very limited. Except in the description of kakawin Nāgarakrtāgama that the kingdoms of Syangka (Siam), Ayodhyapura (Ayuthia), Darmanagari (Dharmarajanagara Ligor), Marutma (Martaban), Rajapura (Rajjpuri), Singhanagari, Campa, Cambodia, and Yawana, as Majapahit's friendly kingdoms (Mitra Satata) (Nag. pupuh 15: 1), is seen as equal kingdoms to Majapahit. Surely the royal elite and clever of Majapahit heard about kingdoms in Southeast Asia through the arrival of traders to Majapahit, so that it is noted by Prapanca.

The contrary views of the mainland Southeast Asian kingdoms to Majapahit cannot be known in-depth, because the investigation of the problem has not yet been carried out. When referring to Panji Stories known to the environment of the mainland Southeast Asian kingdoms (Poerbatjaraka, 1968), it shows that the story developed in the Majapahit era was acceptable to the people of the Southeast Asian kingdoms. The next interpretation is certainly that Majapahit as a kingdom on Java Island is also known by the kings and the royal community in Southeast Asia. Panji story also mentioned other kingdoms such as Janggala, Kadiri, Singhasari, Matahun, Bracelets, and others. Majapahit, of course, is known as a kingdom in East Java that developed in the same atmosphere.

\section{Majapahit's Views of Indian Land (Jambhudwipa) and Vice Versa}

Based on written sources available from the Majapahit era, the people of Majapahit also had their view of India (Jambhudwipa). The people of Majapahit are in around the palace and scholars, namely Brahmins. A growing perception of India includes:

1. Located far from Java (anyadesa), to get to India must cross the vast ocean (Nag.pupuh 83: 4, Pigeaud, 1960, p. 64).

2. One of the two main regions in the world, besides Majapahit (Nag. pupuh 83: 2, Pigeaud, 1960, p. 64). 
3. India as an "old area" or area which is the source of Hindu-Buddhist doctrine, Javanese priests go to India to find out the place of origin of Hindu-Buddhist religion. The book Tantu Panggelaran states that a priest named Batara Mpu Bharang came to visit Jambhudwipa (India) and met Hindus devoting Haricandana (Vishnu) (Pigeaud, 1924, p. 115).

4. The gods from the Jambhudwipa land have moved to Jawadwipa, following the removal of Mount Mahameru, therefore Jambhuwipa is no longer considered important based on religious teachings. Related to the moving of Mahameru from Jambhudwipa to Jawadwipa carried out by the gods because Java is a good place for the development of man, but still shaking buffeted by waves of the ocean, Mahameru moved to Jawadwipa to pacify the island, so it is a narrative in Tantu Panggelaran (Pigeaud, 1924, p. 63 and 65).

5. Jambhudwipa brahmins and their gods are less powerful than Javanese brahmins and Jawadwipa Hyang. It is stated in the book Tantu Panggelaran: "kahucapa ta bhatarampu Bharang, dating sireng bhumi Jambhudipa; kapisticated ta the brahmana mamuja sira ri the hyang Haricandana ... " (Pigeaud, 1924, p. 115). The translation is, "he is Bhatara Mpu Bharang, he goes to India (Jambhuwipa), he meets Brahmins who are worshiping Lord Vishnu (Haricandana)". Furthermore, it is stated in the same book that Mpu Bharang was forced to worship Vishnu statues, but he refused. Mpu Bharang's supernatural power is superior to Indian Brahmins when worshiped by Mpu Bharang the statue of Vishnu is broken, Mpu Bharang states "... apan nghulun brahmana Java" (because I am brahmin [from] Java) (Nurhajarini, 1999, p. 124).

Instead, the views Indians to Majapahit, in particular, are not yet known, because no data can be used to explain it. The views of Indians which can be formulated based on various sources are only related to Nusantara, as follows:

1. Kingdoms consisting of islands (Dvipantara) as mentioned in the book Jataka and Ramayana indicate the existence of islands of Suwarnadwipa, and Jawadwipa (Syafei, 1978, p. 85; Coedes, 2010, p. 35 and 44).

2. Located on a voyage to China, mentioned by Chinese priest I-Tsing in his travel records from China to India, he stopped at Shili Foshi (Sriwijaya) and also mentioned several other areas in Nusantara such as Moluoyou (Malayu), She-po (Java), and Ho-ling (north coast of Central Java) (Takakusu, 2014, p. 53 and 55). In the life history of Atisha Dipamkara Shrijnana, an Indian monk who studied Buddhism in Srivijaya, it is described that Atisha respected the Chinese emperor Tong-Khun who brought prosperity to his kingdom (Tulku \& Glenn H. Mulkin, 1983, p. 3). This means that Atisha understood that Srivijaya (Nusantara) was between India's voyages to China, because she mentioned her home kingdom were India, Srivijaya, and China.

3. The ports are a commercial destination for Indian sailors because they produce gold and local products (spices) (Munoz, 2009, p. 67 and 69).

4. As the same regions which develop Hinduism and Buddhism, other Natra descriptions contained in the book Satya-dvaya-avatara that king of 
Nusantara named Guru-phala is Buddhist and sends a priest named Devamati to study religion in India (Tulku \& Glenn H. Mullin, 1983, p. 49).

\section{Majapahit's Views of China and Vice Versa}

The relation between Java and China has been going for a long time, according to a Chinese report, when the Tarumanagara (To-lo-mo) era which was established in the $5^{\text {th }}$ century, in the $6^{\text {th }}-7^{\text {th }}$ century still sent its envoys to China (Sumadio, 1984, p. 44; Munoz, 2009, p. 240), followed by envoys from the period of Ancient Mataram, Kadiri, Singhasari to Majapahit. Especially in Majapahit era (first half of the $15^{\text {th }}$ century) there has been a visiting fleet of Admiral Cheng-Ho to Java (Majapahit) up to 6 times (Setiawan et al., 1982, pp. 22-24; Yuanzhi, 1993, p. 141; Zarkhoviche, 2015, pp. 141-142). At the beginning of the $15^{\text {th }}$ century, Majapahit was still considerable in Nusantara and Southeast Asia. The arrival of Admiral Cheng-ho, delegated by the Chinese emperor to Java, proves that role of Majapahit is still important. In 7 times of his voyage to "southern kingdoms", he stopped 6 times on Java. The first time, Cheng-ho stopped at the beginning of the $15^{\text {th }}$ century when Majapahit was in a Paregreg war (1404-1406). Cheng-ho witnessed the battle between two parties in Majapahit between Wirakramawarddhana (king of Majapahit, son-in-law of Hayam Wuruk) against Bhre Wirabhumi (son of Hayam Wuruk with his mistress). Cheng-ho and his men stopped in 1406 in the eastern part of the kingdom, unfortunately as many as 170 of Cheng-ho's men were killed in an attack by Wikramawardhana's army. The emperor of China asked for compensation for killing Chinese men, king of Majapahit to pay 60,000 tail of gold (Magetsari, 1979, p. 197; Yuanzhi, 2011, pp. 9192). Cheng-ho's last visit to Java (Majapahit) took place between 1432 , on the $7^{\text {th }}$ trip which took place between 1431-1433 (Yuanzhi, 2011, p. 268). This proves that until around the middle of the $15^{\text {th }}$ century, Majapahit was still strong so that it was worth visiting by Cheng-ho as the official emperor of China.

The views of people around Majapahit palace and scholars (clergy) towards China based on available data can be interpreted as follows:

1. As the region which attacked Java and strong militarily, it is mentioned in the book Pararaton (Hardjowardojo, 1965, pp. 44-46), and Chinese records (Groeneveldt, 2009, p. 31).

2. Source of commodity including ceramics, silk, and nice and expensive items mentioned in the Chinese report (Groeneveldt, 2009, pp. 72-73). The proposition is supported by the findings of thousands of pieces of Chinese macaques from various forms and various dynasties at the Trowulan site. This means that goods from China were bought by the Majapahit people, they knew which ceramics were good from China, then they bought them.

3. Having large sailing ships capable of crossing distant oceans, and the influence of China in Nusantara must always be prevented (Groeneveldt, 2009, pp. 50-51). Reported in the voyage of Admiral Cheng-ho, a fleet of sailing ships China arrived at ports of Tuban, Gresik, Surabaya and Mojokerto (Yuanzhi, 2011, pp. 101-108). The residents around the ports were Majapahit people, of course, witnessing the large ships belonging to the Chinese fleet. 
4. China did not have a cultural relationship with Majapahit because there is no source of ancient Javanese tradition to preach it, unlike India, which is often told in various literary works.

On the other hand, Chinese views of Java (Majapahit) are described directly in their records. Some views of Chinese towards Java (Majapahit) are:

1. Java is located across the ocean and farther from Campa, including the Barbarian state which has not yet submitted to Emperor Shizu (Khubilai Khan) (Groeneveldt, 2009, p. 30).

2. The kingdom (Java) has been tried to be conquered by sending combat troops, but failed and brought disadvantages to China (Groeneveldt, 2009, pp. 31-35).

3. Militarily respected, their soldiers are the best of all barbarian states (Groeneveldt, 2009, p. 56).

4. Destination of Chinese merchants, the people like Chinese porcelain, silk, fragrances, and other valuables goods, they use copper coins, the Chinese currency (copper coin) from various dynasties can be used in trading in this kingdom (Groeneveldt, 2009, pp. 57, 72-73).

5. The community is divided into 3 groups, (a) Chinese traders/merchants, (b) traders from other kingdoms, and (c) local people of Majapahit (Groeneveldt, 2009, p. 56 and 69).

\section{Majapahit's Views of the "Contemporary World"}

Based on the description in Tuhanyaru Inscription (OJO LXXXIII) which dates to 1245 Saka (1323 AD) - issued during the reign of King Jayanagara (13091328) - stated that the Majapahit Kingdom was laid out as a sacred building which occupied the land of Sima. The city of Majapahit as kingship (Rajya i majapahit) likened Prasadha (temple/sacred buildings), a king is Wisnwawatara (statue of Vishnu in temples), Rake Mapatih as pranala (pedestal of the stoned statue), entire Java is mandala which is belonging to his pumpunan (land of sima), while Madura and Tanjongpura are considered as his land of angsa (Djafar, 2012, p. 44).

In the description of an inscription that was younger than from the reign of Hayam Wuruk (1351-1389 AD), namely Bendosari Inscription (OJO LXXXV) was not found some years, but it is estimated that from around $1360 \mathrm{AD}$, there is a description similar to the statement of Tuhanyaru Inscription. Bendosari inscription states as follows:

1.“...makapramuka samantrînggitājnā prajālangkarā, rake mapatih pu mada, sakalanîtiwrha

2.spatisanggramika, prānaraksaka śrî mahārājā pranalāmratisubaddhakên pangdiri śrî mahārājā

3.ngken iśwarapratiwimba..." (Yamin., 1962, p. II: 109)

Translations:

"... especially among ministers who received orders (were) high officials of the kingdom to pass through, (is) Rake Mapatih Pu Mada, who knew all the right paths and wisdom, he who became the jewel of the villages, who always guard Sri Maharaja (Hayam Wuruk), and became a solid pedestal for the establishment of Sri Maharaja as a statue of Iswara (Shiva) ..." 
Based on the description of inscriptions, it is known that in managing its territory, Majapahit has ranks, there are at least 3 ranks (Figure 1), namely (1) the most important rank is the king and his duke of which is likened to a statue of Iswara or Vishnu (the king) which stands on pranala as a symbol of a duke, both located Majapahit city, (2) second, land of the eastern part of Java which was likened to a land of sima-pumpunan as a place for Majapahit kingdom, and (3) third, the areas on other islands outside Java is considered as tanah angsa (land whose resources is for temple's needs, but located far from the temple itself). Data from a description of the inscription of Tuhanyaru and Bendosari can be described as follows:

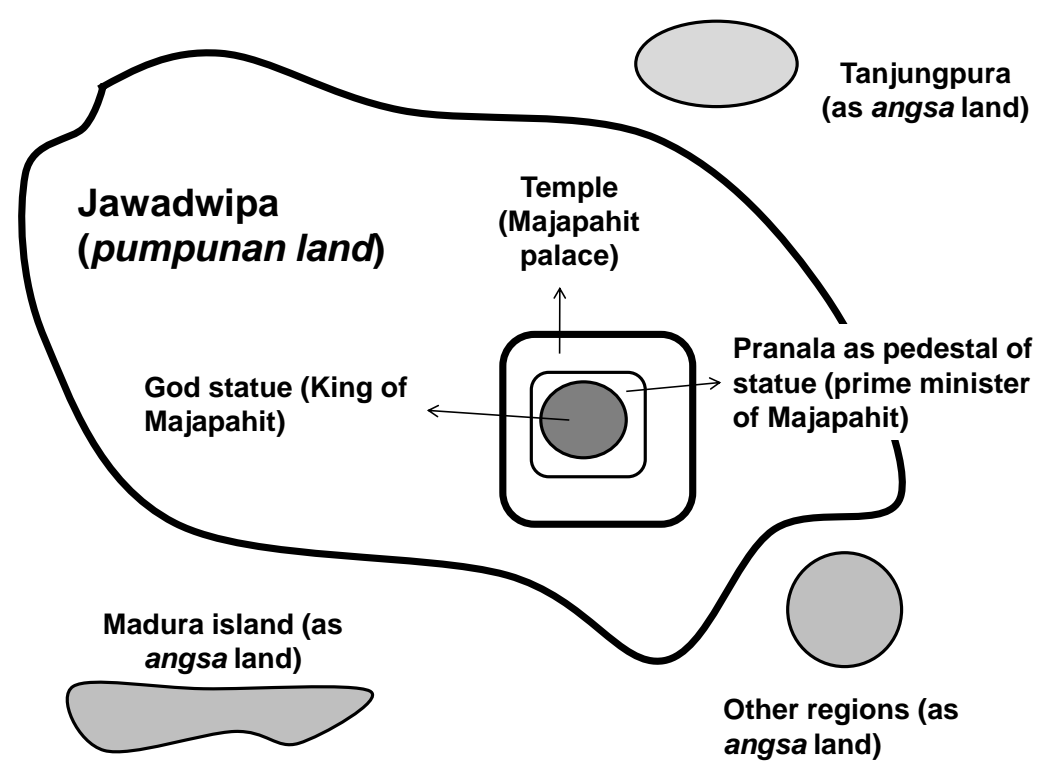

Figure 1. Sketch of Majapahit Region Arrangement based on data from the description of the inscription of Tuhanyaru (1323 AD) and Bendosari (1360 AD)

(Source: A.A. Munandar)

If the arrangement of three ranks is adjusted to a concept of structuring Triangga (nista, madya, uttama), which is still known in Bali, thus there is appropriate compatibility. The concept of Triangga which is the arrangement of territory or land in a concrete (microcosm) refers to the concept of the three worlds 'Triloka' (Bhurloka, Bhuwarloka, and Swarloka) which is the arrangement of the macrocosm (Budihardjo, 1991, p. 35,39 and 40, Munandar, 2005, pp. 176-180). King and duke domiciled in Majapahit city as the main region, while Land of Java (east Java) is an area of rajya i majapahit (kingdom of Majapahit) as madya area, and other regions outside Java which recognize Majapahit power as the outer area that can be likened to nista region.

In the meantime, according to the description of kakawin Nāgarakrtāgama, there is also a territorial division of the contemporary world divided by Majapahit. The division of the world region known by Majapahit people was outlined by Mpu Prapanca in 3 ranks as well. The three ranks can also be synchronized with the 
division of Tri Angga into the territory of nista, madya, and uttama. Kakawin Nägarakrtāgama mentions that Majapahit settlement with Wilwatikta as the place of the king (Nag. pupuh 1:3 and VI: 4), is the most important area and is considered sacred namely Uttama area. Uttama area includes Jawadwipa where Majapahit is located and developed.

Other regions of Nusantara, such as in Sumatra, Borneo, and the Malay Peninsula, in the book Nägarakŗtāgama, are referred to Nusapranusa (Nag. pupuh 13: 1) or Dwipantara (Nag. pupuh 15: 3). The kingdoms of Cambodia, Campa, Syangkayodyapura, Darmmanagari, and others are called Desantara (Nag. pupuh 15: 1). Those kingdoms (in the same pupuh) also called Mitra Satata. The regions called Nusapranusa/Dwipantara and Desantara may be referred to as an area of Madya for Majapahit which is outside of Uttama. The farthest kingdoms from Majapahit, namely India and China in Nägarakrtāgama, is called Anyadesa (Nag. pupuh 83: 4). Those two kingdoms, in Majapahit's view, is appropriate to be called as Nista, as the farthest regions from Majapahit. Based on attention and understanding of Nāgarakrtāgama explanation, it can be interpreted that Majapahit also applies the concept of Tri Angga which refers to the arrangement of macrocosm Tri Loka to look at other areas outside of Majapahit in East Java (Figure 2).

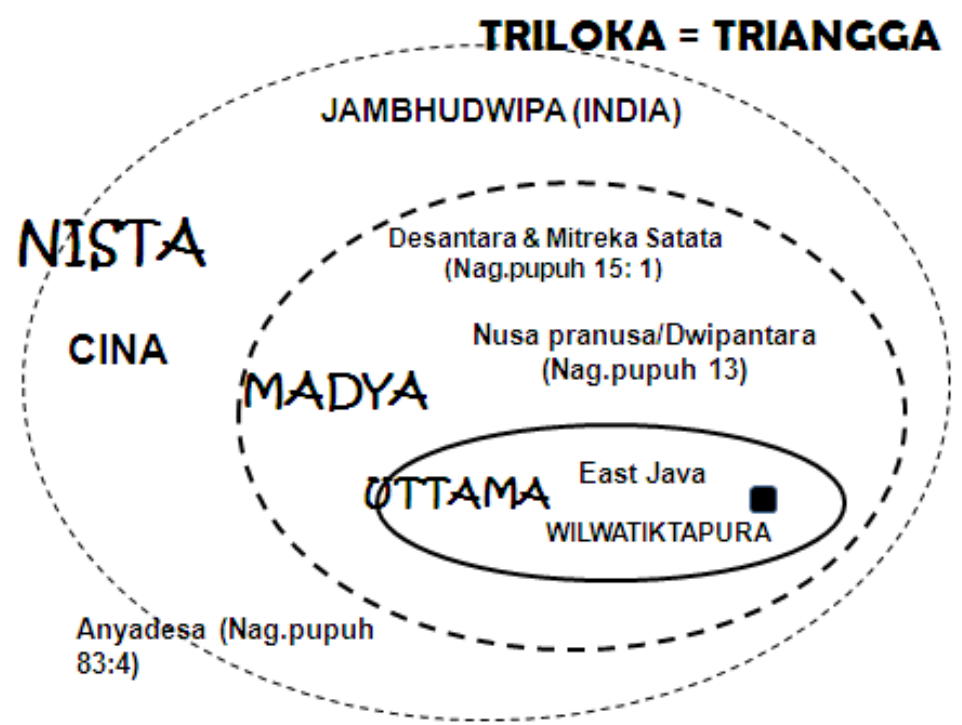

Figure 2. Sketch of Majapahit's views of India and China as the farthest regions (Source: A.A. Munandar)

However, Majapahit's views on other kingdoms can also be described with a different perspective.

1. The area of uttama is rajya i Majapahit (Majapahit city), the place of the king, and the Land of Java (east) where Majapahit is located (Nag. pupuh 1:3 and VI: 4).

2. The area of madya for Majapahit are other kingdoms in Nusantara, including areas in the Malay Peninsula (Nag. pupuh 13).

3. The area of nista are areas that are located distant from Majapahit, Desantara where kingdoms are called Mitra Satata, namely India and 
China. The regions are all called as Anyadesa (pupuh 83: 4 in Nägarakrtāgama (... " sakeng anyadesa prakirnna, nang jambhudwipa, khamboja china yawana len/Cempa kharnnatakadi, goda mwang syangka ...") (Pigeaud, 1960, p. 64). Then Anyadesa includes Jambhudwipa, Cambodian (Khmer), China, Yawana, Campa, Kharnnataka, Goda, and Syangka, that regions are called nista by Majapahit in the depiction on a map (Figure 3).

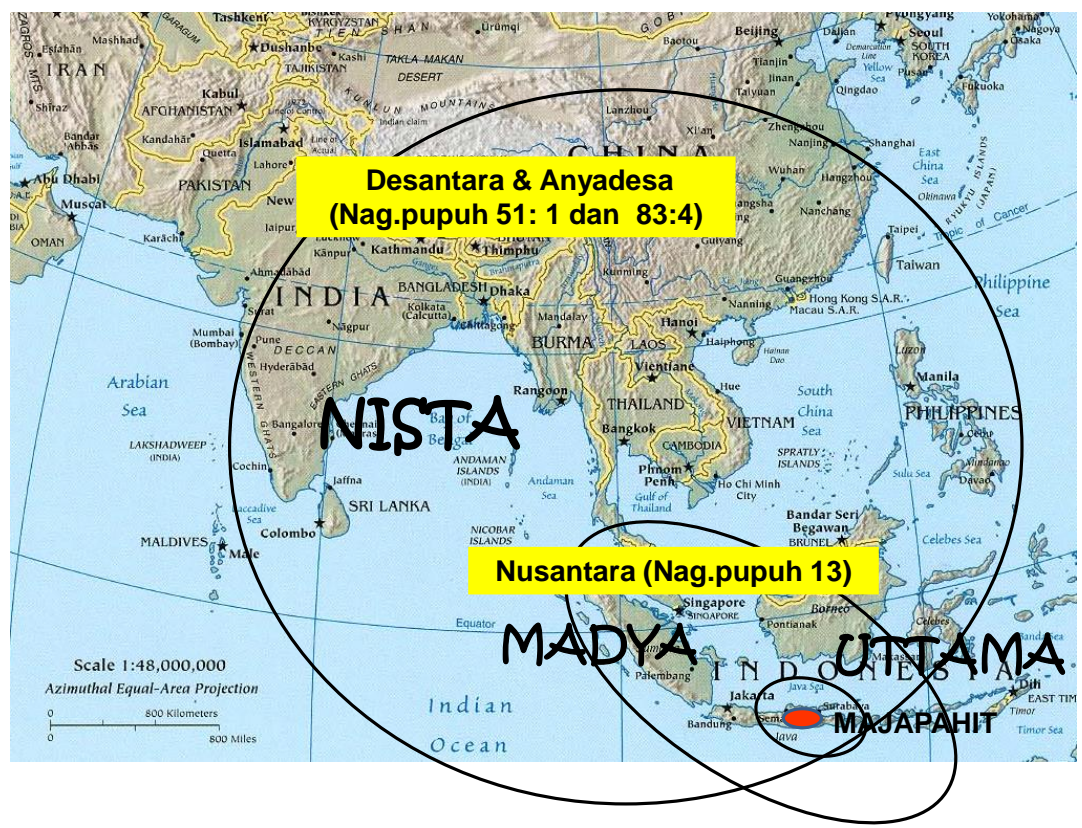

Figure 3. Sketch of a depiction of an area of nista, middle, and uttama according to Kakawin Nāgarakrtāgama

(Source: A.A. Munandar)

Those perspectives, which is more appropriate cannot be ascertained, because both perspectives are mentioned by Mpu Prapanca in Nāgarakŗtāgama. This study cannot decide which perspective that Majapahit has chosen. The difference in perspective may be based on different reasons, but there is no data to reveal the reasons underlying that perspective. It is important to know that Majapahit already has a conception of looking at the kingdoms that developed contemporaneously. As a great kingdom, Majapahit certainly needs a conception in looking at surrounding areas. The conception is taken from known religious doctrine, namely the division of three worlds (Tri Loka) which are concrete in the form of arrangement of Tri Angga areas.

\section{CONCLUSIONS}

Majapahit was known as one of the great kingdoms in Southeast Asian regions in the $14^{\text {th }}$ century until the $15^{\text {th }}$ century. Various narratives of Majapahit's relationship with foreign kingdoms or Nusantara have been described in the previous section. Based on the discussion that has been done, it can be interpreted related to the power of Majapahit in terms of interaction with various kingdoms known in the same period. The power of Majapahit in interacting with various 
kingdoms covers four things: 1) power of the military, 2) as a benchmark of civilization, 3) power of trading and relation to other regions, and 4) basic conception of Majapahit's views of the "Contemporary World".

Majapahit military force was once used to conquer Bali, Dompo, and Tumasik, by deploying its fleet and army to attack these areas. There were some influences of Majapahit that develop continuously in its controlled territories, such as in Bali, but many influences faded and disappeared after Majapahit decline gradually at the end of the $15^{\text {th }}$ century.

Majapahit is recognized as a great kingdom that deserves to be used as a reference in various ways, such as in the fields of state administration, government politics, and the achievement of other civilizations. The rulers of Nusantara declared their admiration for the king of Majapahit by sending their envoys to Majapahit palace each year. King of Majapahit was pleased to receive the envoys who came to the palace and offered gifts from their regions, but only delivered gifts because the independent regions do not always have to be occupied by the Majapahit army.

In addition to holding relations in trading with the people, Majapahit held trading activities with several kingdoms which are located in Southeast Asia or outside of Southeast Asian regions, such as areas of Jambhudwipa (India) and China. This form of relationship was very flexible, Prapanca in Nägarakŗtāgama only mentions that some priests and merchants from the land of Jambhudwipa came to Majapahit. As for China, there were reports about the arrival of Chinese merchants who had transactions at the ports of Majapahit and in Majapahit city.

In the first half of the $15^{\text {th }}$ century, Admiral Cheng-ho from China had several times of goodwill visits to Java, where the ports of Majapahit at that time were still crowded with commercial activity. Merchants from various regions of Nusantara and Southeast Asia were still arriving and trading in northern coastal ports of East Java. In the second half of the $15^{\text {th }}$ century, the authority of Majapahit had declined, due to internal conflicts and power struggles among royal relatives who were still members of Rajasa, resulting in trading activities especially with China not being crowded anymore.

During its development, Majapahit held interactions with various regions. In general, the relationships were going well, only 3 times Majapahit attacked some regions of Nusantara, such as to Bali, Dompo in Sumbawa (described in Nägarakrtāgamma), and Tumasik (described in the book of Malay History). Nägarakrtāgama also states that in the era of Hayam Wuruk's rule occurs a great pasewakan (meeting) in Majapahit palace each year. This shows the existence of Majapahit's good relations with other regions. Because in a homage ceremony to the king, many envoys from various kingdoms came to come before the king. Perhaps the Seba ceremony (a homage ceremony to the king) was continuing during the reign of following kings, only splendor of ceremony decreasing and all guests who came also decreasing.

Based on the description of Tuhanyaru inscriptions (1323 AD) and Bendosari inscriptions ( \pm 1360$)$, the arrangement of the Majapahit kingdom region is likened to a prasadha containing God statues which based on pranala in sima-pumpunan land and equipped with its angsa land. Also, in Nägarakrtāgama known that the arrangement reflects the concept of Tri Angga which divides regions into nista 
(unholy regions, edges, far from main regions), madya (middle regions, where various activities support main regions), and uttama (main and holy regions). In the meantime, the concept of Tri Angga is an embodiment of an arrangement of the universe which is divided into three called the concept of Tri Loka including Bhurloka (nista), Bhuwarloka (madya), and Swarloka (uttama).

The concept of Tri Angga according to the description of Nägarakrstāgama can be seen when Majapahit's views of other regions or contemporary kingdoms. One of the details is that Majapahit in Java (east) as uttama region, other islands (Nusantara) and the Malay Peninsula are madya regions, while Mitra Satata's kingdoms in mainland Southeast Asia, India and China are seen in the level of nista that the regions located at relatively far from Majapahit and was not often directly related to rajya i Majapahit.

Majapahit was the biggest and the last Hindu-Buddhist kingdom before Islam developed rapidly in the Nusantara islands. In the Majapahit period, achievements of Hindu-Buddhist civilization have been "become Javanese". The religious relationship with the land of origin of both religions, namely India, was very limited, therefore ancient Javanese Brahmins and clerics of the Majapahit era could reinterpret Hindu-Buddhist doctrine and conceptions according to the version of ancient Javanese culture. This study is brief, actually trying to discuss some Hindu-Buddhist postulates of ancient Javanese in the Majapahit era. The result is not necessarily a correct conclusion, but at least it can increase understanding of how the role of Majapahit concerning other contemporary regions, and Majapahit's conceptual view of other regions or kingdoms known at the same era.

In the end, it can be stated that Majapahit already has a perspective and puts contemporary kingdoms in its interactions with those kingdoms. This perspective is based on a territorial arrangement that referred to Hindu-Buddhist religious doctrine as a religion that was embraced by many rulers and people at that time. 


\section{BIBLIOGRAPHY}

Budihardjo, E. (1991). Architectural Conservation in Bali. Yogyakarta: Gajah Mada University Press.

Cribb, R. \& Kahin, A. (2012). Kamus Sejarah Indonesia. Depok: Komunitas Bambu.

Djafar, H. (2012). Masa Majapahit Akhir: Girindrawarddhana \& Masalahnya. Depok: Komunitas Bambu.

Groeneveldt, W.P. (2009). Nusantara dalam Catatan Tionghoa. Depok: Komunitas Bambu.

Hardjowardojo, P. (1965). Pararaton. Djakarta: Bhratara.

Ikram, Achadiati. (2019). Pengantar Penelitian Filologi. Jakarta: Masyarakat Pernaskahan Nusantara (Manassa).

Magetsari, N. (1979). Kamus Arkeologi Indonesia 2. Laporan Fakultas Sastra Universitas Indonesia untuk Proyek Penelitian Bahasa dan Sastra Indonesia dan Daerah. Departemen Pendidikan dan Kebudayaan. Jakarta.

Munandar, A. A. (2005). Istana Dewa Pulau Dewata: Makna Puri Bali Abad ke-14 - 19. Depok: Komunitas Bambu.

Munandar, A. A. (2014). "Panji dan para Kadeyan Mengembara dalam Kebudayaan Nusantara", dalam Prosiding Seminar Tokoh Panji Indonesia: Panji dalam Berbagai Tradisi Nusantara, pp. 1-19. Jakarta: Direktorat Pembinaan Kesenian dan Perfilman, Ditjen Kebudayaan.

Mulyana, Slamet. (1979). Nagarakertagama dan Tafsir Sejarahnya. Jakarta: Bhratara.

Munoz, P. M. (2009). Kerajaan-kerajaan Awal Kepulauan Indonesia dan Semenanjung Malaysia: Perkembangan Sejarah dan Budaya Asia Tenggara (Jaman Pra SejarahAbad XVI). Yogyakarta: Mitra Abadi.

Nurhajarini, Dwi Ratna. (1999). Kajian Mitos dan Nilai Budaya dalam Tantu Panggelaran. Jakarta: Proyek Pengkajian dan Pembinaan Nilai-nilai Budaya, Direktorat Sejarah dan Nilai Tradisional, Ditjen Kebudayaan, Depdikbud.

Pigeaud, Th. G. Th. (1924). De Tantu Panggelaran: Een Oud-Javaansch Prozageschrift Uitgegeven, Vertald en Toegelicht. Disertasi, Rijksuniversiteit te Leiden. 'sGravenhage: Nederlandsche Boeken Steendrukerij vh.H.L.Smits.

Pigeaud, Th. G. Th. (1960-1963). Java in The 14th Century A Study in Cultural History: The Nagara-kertagama By Rakawi Prapanca of Majapahit, 1365 AD. Volume I$V$. The Hague: Martinus Nijhoff.

Poerbatjaraka, R. M. Ng. (1968). Tjeritera Pandji dalam Perbandingan. Translated by Zuber Usman and H.B. Jassin. Djakarta: PT.Gunung Agung. 
Pudjiastuti, Titik. (2016). “Naskah Kuno Sebagai Sumber Kearifan Lokal dan Pengetahuan Budaya Indonesia: Solusi untuk Membaca dan Memamhami Produk Budaya Indonesia". In Riris K.Toha Sarumpaet (editor), Krisis Budaya: Oasis Guru Besar Fakultas Ilmu Pengetahuan Budaya UI, hlm. 245-263. Jakarta: Yayasan Pustaka Obor Indonesia..

Putra, I. B. Rai. (1991). Babad Arya Kutawaringin. Denpasar: Upada Sastra.

Putra, I. B. Rai. (1995). Babad Dalem. Denpasar: Upada Sastra.

Ras, J. J. (1968). Hikayat Bandjar: A Study in Malay Historiography. The Hague: Martinus Nijhoff.

Robson, S. O. (1994). Prinsip-prinsip Filologi Indonesia. Terjemahan Kentjanawati Gunawan. Jakarta: RUL.

Setiawan, E. et al. (1982). Mengenal Kelenteng Sam Poo Kong Gedung Batu, Semarang. Semarang: Yayasan Kelenteng Sam Poo Kong Gedung Batu.

Situmorang, T.D., A.Teeuw, and Amal Hamzah. (1952). Sedjarah Melaju Menurut terbitan Abdullah (ibn Abdulkadir Munsji). Djakarta: Djambatan.

Sumadio, B. (ed.). (1984). Sejarah Nasional Indonesia II: Jaman Kuna. Jakarta: Balai Pustaka.

Sutrisno, S. (1985). Sekilas Rona Kebudayaan Jawa dalam Karya Sastra Melayu Lama. In Sulastin Sutrisno, Darusuprapta, Sudaryanto (Eds.), BahasaSastra-Budaya: Ratna Manikam Untaian Persembahan kepada Prof.Dr.P.J.Zoetmulder, pp. 354-69. Yogyakarta: Gadjah Mada University Press.

Syafei, S. (1978). Pengaruh Kebudayaan India di Asia Tenggara. Berita Antropologi: Majalah Ilmu Sosial dan Budaya, IX, (32-33), pp. 81-90.

Tulku, Doboom \& Glenn H. Mullin. (1983). Atisha and Buddhism in Tibet. New Delhi: Tibet House.

Yuanzhi, K. (1993). Sam Po Kong dan Indonesia. (Editor H. M. Hembing Wijayakusuma) Jakarta : CV. Haji Masagung.

Yuanzhi, K. (2011). Cheng Ho Muslim Tionghoa: Misteri perjalanan muhibah di Nusantara. Jakarta: Yayasan Pustaka Obor.

Zarkhoviche, B. (2015). Laksmana Cheng-ho Panglima Islam Penakluk Dunia : Kisah Ekspedisi Tionghoa Muslim Terbesar Sepanjang Sejarah. Yogyakarta : Araska. 